\title{
Hospitalization in Adolescence and Young Adulthood Among Twins and Singletons: A Swedish Cohort Study of Subjects Born Between 1973 and 1983
}

Marie Bladh, John Carstensen, Ann Josefsson, Orvar Finnström and Gunilla Sydsjö

\author{
Linköping University Post Print
}

\section{Tweet}

N.B.: When citing this work, cite the original article.

Original Publication:

Marie Bladh, John Carstensen, Ann Josefsson, Orvar Finnström and Gunilla Sydsjö, Hospitalization in Adolescence and Young Adulthood Among Twins and Singletons: A Swedish Cohort Study of Subjects Born Between 1973 and 1983, 2013, Twin Research and Human Genetics, (16), 3, 707-715.

http://dx.doi.org/10.1017/thg.2013.27

Copyright: The Authors

Postprint available at: Linköping University Electronic Press http://urn.kb.se/resolve?urn=urn:nbn:se:liu:diva-94317 


\section{Original Article}

Hospitalization in adolescence and young adulthood among twins and singletons A Swedish cohort study of subjects born 1973-1983

Bladh M, *, Carstensen J †, Josefsson A*, Finnström O †, Sydsjö G *

* Division of Obstetrics and Gynaecology, Department of Clinical and Experimental Medicine, Faculty of Health Sciences, Linköping University, Department of Obstetrics and Gynecology in Linköping, County Council of Östergötland, Linköping, Sweden

$\dagger$ Division of Health and Society, Department of Medical and Health Sciences, Faculty of Arts and Science, Linköping University, Sweden

$\$$ Division of Pediatrics, Department of Clinical and Experimental Medicine, Faculty of Health Sciences, Linköping University, Sweden

Running title: Hospitalization among twins and singletons as young adults

Correspondence: Marie Bladh

Department of Obstetrics and Gynaecology

University Hospital

SE - 58185 Linköping, Sweden

Tel: +4610103 8350; fax: +4613148156

e-mail: marie.bladh@liu.se 
Abstract: Children born with non-optimal birth characteristics, i.e. small for gestational age (SGA) and/or preterm, have an increased risk for several long term effects such as neurological sequelae and chronic disease. The purpose of this study was to examine whether twins exhibited a different outcome, compared to singletons, in terms of hospitalization during adolescence and early adulthood and to what extent differences remain when considering the divergence in birth-characteristics between singletons and twins.

Persons born 1973-1983 in Sweden and surviving till age 13 were included and followed until the end of 2006. Data on birth characteristics, parental socio-demographic factors and hospitalizations were collected from national registers.

Adjusting for parental socio-demographic factors, twins had a higher risk of being hospitalized than singletons (odds ratio: $1.17,95 \%$ confidence interval: $1.10-1.25$ ) and more often due to "Congenital anomalies" (OR=1.18, 95\% CI=1.06-1.28), "Infections" (OR 1.14; CI 1.08-1.20), "External causes of illness" (OR 1.10; 1.06-1.15), "Diseases of the nervous system" (OR=1.18, 95\% CI=1.10-1.26). Stratifying for birth characteristics this difference diminishes and for some diagnoses non-optimal twins seem to do slightly better than nonoptimal singletons. Thus, twins with non-optimal birth characteristics had a lower risk of hospitalization than non-optimal singletons on e.g., "Congenital anomalies", and "Diseases of the nervous system" $(\mathrm{OR}=0.86,95 \% \mathrm{CI}=0.77-0.96, \mathrm{OR}=0.88,95 \% \mathrm{CI}=0.81-0.97$, respectively) and on all causes $(\mathrm{OR}=0.87,95 \% \mathrm{CI}=0.83-0.92)$. Among those with optimal birth characteristics twins had an increased hospitalization due to "External causes of illness" $(\mathrm{OR}=1.07,95 \% \mathrm{CI}=1.02-1.13)$ compared to optimal singletons.

Twins have higher hospitalization rates than singletons. Stratifying for birth characteristics this difference diminishes and for some diagnoses non-optimal twins seem to do less poorly than non-optimal singletons. 
It is well established that twin pregnancies involve more risks during pregnancy and delivery compared to singleton pregnancies. This elevated risk can be attributed to the high number of premature births and/or growth restriction but also due to delivery complications among term pregnancies, though the latter cause has declined (Mongomery et al. 2005a, 2005b).

Recent studies provide extensive documentation that being born preterm and/or with low/very low birth weight and/or SGA has a long-term effect on the person's future morbidity (Ekholm Selling et al., 2008). Prematurity has been shown to cause long-term sequelae such as cerebral palsy, retinopathy of prematurity (ROP) and mental retardation (Moster et al., 2008; Quinn et al.,2010). Intrauterine growth restriction is associated with an increased risk of obesity, type 2 diabetes, hypertension, psychiatric disorders and also exhibits a potential increased risk for cardiovascular disease.

However, the long-term outcome for children born premature and/or small for gestational age (SGA) may be different for twins than singletons since the cause of prematurity among twins is, generally, of a different character than the cause of singletons' prematurity. Among all premature births about $30-40 \%$ are due to maternal infections, while among twin premature births the lack of space is the major cause of prematurity (Goldenberg et al., 2008; Romero et al., 2008)

Also, very few studies have focused on the potential effect twinning may have on general future health outcomes and hence very little is known about the risk for long-term morbidity associated with twin pregnancy and delivery.

The purpose of this study was to examine whether twins exhibited a different outcome, in comparison with singletons, in terms of hospitalization as proxy for morbidity during adolescence and early adulthood and to what extent differences remain when considering the divergence in birth-characteristics between singletons and twins. We also wanted to examine to what extent the association of long-term health outcomes with birth characteristics differed 
between twins and singletons.

We have identified 16,561 twins - which approximately equals 8,000 twin pairs - in national health registers. These data provide a unique source for exploring the importance of being born a twin, compared to singletons, and its effect on future morbidity.

\section{Material and methods}

\section{Data}

The data for this study were retrieved from Swedish population-based registries. All Swedish residents are assigned unique personal identification numbers, which enables us to individually link the information in the different registers. All registers have been validated.

- $\quad$ The Swedish Medical Birth Register (MBR): The MBR contains information on all births since 1973 and onwards and is held by the Swedish National Board of Health and Welfare (National Board of Health and Welfare, 2003).

- $\quad$ The Total Population Register (TPR) and the Multi-Generation Register: The TPR is held by Statistics Sweden and was established in 1968 (Statistics Sweden, 2002, 2009a). The register contains information on variables such as births, deaths, migrations, and marital status. The Multi-Generation Register is founded on information from the TPR and enabled us to identify the fathers of the studied men and women (in the MBR only information on the mother is included) (Statistics Sweden, 2010).

- $\quad$ The National Patient Register (NPR) and the Causes of Death Register: The National Board of Health and Welfare registers all public in-patient care in the NPR since 1987 (National Board of Health and Welfare, 2008, 2010a, 2010b, 2010c; Johansson et al., 2000; D'Amico et al., 1999) and since 1997 outpatient visits are included. The Causes 
of Death Register contains information on the cause and date of death and was established in 1961.

- The Education Register and the Population and Housing Census: Since 1985, Statistics Sweden continuously collects information on the educational level of the population (Statistics Sweden, 2009b, 2006, 1974).

Our study population was defined as "twins and singletons born and still living in Sweden at the age of 13". The starting age of 13 was chosen because the focus was on long-term morbidity. A total of 1,070,380 births were registered in 1973 - 1983 according to both MBR and TPR, of these 10,811 individuals (1\% of all singletons) were deceased before the age 13, 10,023 singletons, 776 twins (4 \% of all twins) and 12 with unknown twin status. Persons with missing values on birthweight $(n=2,114)$ and on gestational length $(n=4,840)$ were excluded. Cases that were considered to have an extremely high birthweight with respect to gestational length were excluded $(n=663)$. Also, 3,629 cases with an unlikely low birth weight with respect to gestational length were excluded from the analysis. Persons who had emigrated, and not returned to Sweden, before the age of $13(n=20,507)$ or immigrated to Sweden at age 14 and onwards ( $n=5,485)$ were excluded. Finally, 5,423 individuals were removed due to lack of information on the father of the child. The final data set, after removal of triplets or higher order pregnancies $(n=220)$, comprised 1,016,688 individuals, out of these a total of 16,561 twins could be identified, as indicated by the medical birth register.

\section{Variables and definitions}

"Small for gestational age" (SGA) was defined as a birth weight $<-2$ SD of the mean weight for the gestational length (Marsal et al., 1996), "Large for gestational age” (LGA) as a birthweight $>+2 \mathrm{SD}$ of the mean weight for the gestational length according to the Swedish 
standard (Marsal et al., 1996). “ Low birthweight” was defined as birthweight below $2500 \mathrm{~g}$ and "very low birthweight" as a birthweight below 1500 g. "Moderate preterm birth" was defined as being born between gestational week 32 and 36, and "very preterm birth" as being born before gestational week 32 . In most of the analyses birth characteristics were combined and dichotomized into "optimal" including children born at term and appropriate for gestational age (AGA) and," non-optimal” including children born SGA or preterm.

"Educational level" was separated in to three categories: 'elementary school', 'high school' 'and graduate/postgraduate'. "Parental country of origin" was dichotomized into 'both parents from Nordic countries' and 'one or both from non-Nordic countries'. "Mother's marital status" had three levels: 'married', 'unmarried' and 'divorced/widowed'. "Parity” was defined as either 'no previous deliveries' or 'one or more previous deliveries'. "Mother's age when giving birth" was separated in to four categories: 13-19 years, 20 - 26 years, 27 - 33 years and $\geq 34$ years.

Missing values on country of origin and marital status were all imputed with the most common value for each variable (360 cases were imputed on marital status and 8 cases on maternal country of origin and 18 cases on paternal country of origin).

Hospitalization was used as a proxy for morbidity and was dichotomized into two levels " 1 or more hospitalizations" and "no hospitalizations", one for each of the studied diagnosis. Consequently it did not measure morbidity, but rather whether individuals had been hospitalized during the study period. Total (all-cause) hospitalization was further dichotomized into $<6$ and $\geq 6$. Analysis of hospitalization was limited to adolescence and young adulthood (the youngest cohort was followed till age 23 and the oldest cohort till age 33). The diagnoses studied were based on the Swedish versions of the International 
Classification of Diseases (ICD), ICD 9 and ICD 10, and were based on the three digit codes which equal the main chapters in order to capture the general morbidity within each ICD chapter. The ICD chapters also provide a well-established and well known grouping of the diseases. In the analysis ICD 10 codes have been converted to match ICD 9 codes and, hence, only ICD 9 is reported in the tables.

\section{Statistical Analysis}

Logistic regression was used to calculate hospitalization odds ratios in twins compared to singletons (Table 3). This analysis was also done in sub-groups defined by birth characteristics ('optimal'/ 'non-optimal') (Table 4). Furthermore, separating twins and singletons, we analyzed hospitalization odds ratios in individuals with 'non-optimal' birth characteristics compared with those born 'optimal' (Figure 1). In all these analyses, adjustments were made for socio-demographic factors (parental level of education, mother's age when giving birth, mother's civil status when giving birth, parity and study subjects year of birth and gender). In addition, logistic regression was used to estimate the twin-versussingleton odds ratio in relation both to socio-demographic variables (Table 1) and to the different birth characteristics (Table 2). Analyses were performed using IBM SPSS, version 19.0 (IBM SPSS Inc., Armonk, NY), however, confidence intervals for the odds ratios have been adjusted for the intra-pair-correlation between $1^{\text {st }}$ and $2^{\text {nd }}$ born twin, using cluster design effect formulas(Kirkwood \& Sterne, 2003)

\section{Results}

\section{Socio-demographic and birth characteristics}

When performing a multiple logistic regression including socio-demographic characteristics at time of birth, the odds for being a twin was statistically significantly increased with older mothers and among those where the mother had had previous deliveries (Table 1). The odds for being a twin were higher for females and for those born in the later part of the studied 
period.

(Table 1 about here)

Twins were found to be smaller for gestational age, had a lower birth weight and were born at an earlier gestational age compared to singletons (Table 2). This also holds true when controlling for socio-demographic characteristics at birth.

(Table 2 about here)

\section{Hospitalization}

Adjusting for socio-demographic characteristics, twins had increased odds of ever being hospitalized compared to singletons as well as increased odds of having 6 or more hospitalizations (Table 3). When analyzed by diagnosis grouped according to ICD main chapters, twins were found to have increased odds of being hospitalized for "Infections and parasitic diseases", "Diseases of the nervous system", "Diseases of the digestive system" “Congenital anomalies and "External causes of illness". Twins showed decreased odds of hospitalization for "Symptoms, signs and ill-defined conditions" compared to singletons. (Table 3 about here)

In Figure 1 hospitalization odds ratios in individuals with non-optimal compared with those with optimal birth characteristics are displayed for twins and singletons separately. In singletons, non-optimal birth characteristics were associated with increased odds of being hospitalized for each ICD 9 diagnoses chapter as well as for total hospitalization and for $6 \geq$ hospitalizations. The general pattern in twins was similar to that of singletons, however, regarding total hospitalization and most diagnoses chapters the OR tended to be lower than those in singletons.

(Figure 1 about here) 
To evaluate to what extent the difference between singletons and twins remains when considering differences in birth characteristics, the material was stratified into two groups according to optimality at birth, optimal (AGA and term) or non-optimal (SGA or preterm birth).

This analysis (Table 4), where it was controlled for socio-demographic variables, revealed that there were no differences in "Total hospitalization" or "Hospitalization $\geq 6$ times" between optimal twins and singletons. However, twins had higher odds of hospitalization due to "External causes of illness" and reduced odds of hospitalization due to "Mental disorders", "Diseases of the respiratory system" and "Symptoms, signs and ill-defined conditions" compared to singletons. In the non-optimal group twins exhibited reduced odds of ever being hospitalized compared to singletons. Furthermore, twins had lower odds of hospitalization for several diagnoses; "Endocrine, nutritional, and metabolic diseases”, "Mental Disorders", "Diseases of the respiratory system", "Diseases of the genitourinary system", "Diseases of the musculoskeletal system and connective tissue"; and "Symptoms, signs, and ill-defined conditions" compared to singletons.

(Table 4 about here)

Model validations included investigation of possible two-way interaction effects between parental education and twinning as well as gender and twinning. Significant interactions between twinning and gender were found for "Diseases of the genitourinary system" ( $\mathrm{p}=0.001)$, "Symptoms, signs and ill-defined conditions" $(\mathrm{p}=0.007)$ and "Total hospitalization" ( $\mathrm{p}=0.001)$. Statistically significant interactions were also found for twinning and father's educational level for "Endocrine, nutritional and metabolic diseases and immunity disorders " ( $\mathrm{p}=0.008)$. Finally, statistically significant interactions were also found between 
twinning and mother's educational lever for "Diseases of the circulatory system" $(p=0.009)$ and "External causes of morbidity and mortality" ( $\mathrm{p}=0.002)$.

To adjust also for non-optimal sub type (Table 4, last column) the hospitalization odds ratio for non-optimal twins compared to non-optimal singletons were adjusted for both sociodemographic characteristics and birth characteristics, i.e. weight for gestational age and degree of prematurity (defined as gestational week in Table 2). Not only did twins exhibit a lower likelihood for hospitalization on total hospitalization but also on several diagnoses ("Endocrine, nutritional and metabolic diseases", "Blood diseases", "Mental disorders", "Diseases of the nervous system", "Diseases of the respiratory system", "Diseases of the genitourinary system", "Diseases of the musculoskeletal system and connective tissue", "Congenital anomalies" and "Symptoms, signs and ill-defined conditions") compared to singletons.

\section{Discussion}

In this study hospitalization was used as a proxy for morbidity, and utilizing data from national health register the hospitalization among twins compared to singletons was analyzed, this is discussed in further detail below. We found that twins had an overall higher number of hospitalizations during childhood, adolescence and early adulthood, when adjustment for socio-demographic variables was done. This was not unexpected considering the divergence in birth-characteristics between twins and singletons and the extensive evidence from earlier studies of poorer long-term health in individuals born preterm or SGA (Ekholm Selling et al., 2008). As present study also shows these health effects of being born non-optimal are essentially similar in twins and singletons (Figure 1).

Previous studies on the importance of twinning with respect to morbidity and mortality are 
somewhat inconclusive (Cunningham et al., 1997). Despite this twins have, in several studies, been found to have increased odds for neonatal morbidity and mortality (Cooke, 2010; Ananth $\&$ Sulian, 2005). Studies have also indicated that when looking at congenital malformations rates (all diagnoses included) no differences have been found between twins and singletons (Cooke, 2010). However, when looking at specific diagnoses such as cerebral palsy, several studies report increased odds for twins (specifically monozygotic twins) (Cooke, 2010; Scher et al., 2002). These findings were confirmed in this study.

We also found, when stratifying by optimality at birth, that these differences diminishes or even are reversed for some ICD chapters. However, increased odds of being hospitalized due to external causes were still found for optimal twins in comparison to optimal singletons. A possible explanation to twins' increased odds for hospitalization due to "External causes of illness" could be the twinning itself. Being a pair could possibly lead to them challenging one another and hence become more adventurous than singletons. Also, it is more challenging to attend two children of the same age compared to one (Segal, 2010). It should also be noted that in individuals with optimal birth characteristics, hospitalization odds (in adolescence and early adulthood) were lower in twins for "Mental disorders", "Respiratory diseases" as well as for "Symptoms, signs, and ill-defined conditions".

When the comparisons were restricted to twins and singletons with non-optimal birth characteristics and adjusting for both socio-demographic and birth characteristics (i.e. also allowing gestational size and degree of prematurity to vary), the twins did somewhat better in comparison to singletons for a number of diagnoses (ICD 9 chapters "Endocrine, nutritional and metabolic diseases", "Blood diseases", "Mental disorders", "Diseases of the nervous system", "Diseases of the respiratory system", "Diseases of the genitourinary system", 
"Diseases of the musculoskeletal system and connective tissue", "Congenital anomalies", and "Symptoms, signs, and ill-defined conditions"). The reason for this is probably that the causes of non-optimal birth characteristics differ between twins and singletons. Singletons are often delivered prematurely due to pregnancy complications such as infections, while children in multiple pregnancies often are delivered preterm due to lack of space (Goldenbert et al., 2008, Romero et al., 2008). Both infections and multiple pregnancies are known risk factors for premature delivery as is maternal age and smoking (Goldenberg et al., 2008, Romero et al., 2008, M, Tandberg et al., 2007). This was validated in the analysis when data was stratified on optimal/non-optimal birth characteristics where twinning mainly had an effect in the strata for non-optimal birth characteristics. This suggests that twins born in the non-optimal category, even though dealing with several health issues, do somewhat better than singletons on these conditions. Same implications from twin-ship have been reported on fetal mortality and risk for cerebral palsy (Scher et al., 2002).

This is a population-based study in which all children born between 1973 and 1983 and who were still alive and still living in Sweden at the age of 13 were included. The major strength of the study is that it is population based and therefore includes a large number of individuals. All data were prospectively collected from registers maintained by The Swedish National Board of Health and Welfare and Statistics Sweden. These registers are evaluated regularly and cover $99 \%$ of all newborns. The reporting to the NPR is complete for inpatient hospital care and $98.6 \%$ of all incidents are correctly classified (National Board of Health and Welfare, 2008, 2010a). We used NPR to study hospitalization rather than morbidity since outpatient data were not available until 1997. Moreover, hospitalization was dichotomized since the likelihood for hospitalization and the duration for some diagnoses have changed over time. Also, through the unique personal identification numbers we were able to link data on socio- 
demographic variables with data on their births and hospitalizations, which allowed for thorough/extensive analysis. The data did not allow us to control for homozygotic and dizygotic twins. However, the primary goal in this study was to analyze potential differences between twins and singletons, regardless of the twin being homozygote or dizygote. Another potential problem is the estimation of gestational length in twin pregnancies. It is possible that twins' gestational age sometimes is underestimated due to a very early intrauterine uterine growth restriction (IUGR) and hence causing a bias in the analyses. Finally, since the study population was defined as persons born between 1973 and 1983 the twinning rate in this study was not affected by in vitro fertilization (IVF) treatment. Nor had hormone stimulation without IVF any major effect, the twinning rate in the study period rose marginally, from 8.2 to 9.1twin births/ 1000 women (National Board of Health and Welfare, 2009). Since 1983 there has been a marked increase of twin births in Sweden (National Board of Health and Welfare, 2009) as well as globally (Imaizumi, 1997). The increase in twinning rates is partly due to IVF, but also hormone stimulation without IVF. Another contributing factor is the increasing maternal age (Tandberg et al., 2007; Fellman et al., 2005), which further motivates the need for investigating the morbidity among twins.

\section{Conclusions}

In the total study cohort twins generally had higher odds of being hospitalized than singletons. When the cohort was grouped into those with optimal and non-optimal birth characteristics, i.e. small for gestational age and/or preterm birth respectively, twins born with non-optimal birth characteristics had a reduced odds of being hospitalized due to "Congenital anomalies", "Diseases of the nervous system" and "Diseases of the genitourinary system" when adjusting for both socio-demographic and birth characteristics. Compared to optimal singletons, optimal twins exhibited an increased likelihood of being hospitalized due to "External causes of 
illness". 


\section{References}

Ananth C.V., Sulian J.C. (2005) Trends in congenital malformations, chromosomal anomalies and infant mortality among twin births. In: Blickstein I, Louis G. Keith LG (Eds). Multiple Pregnancy Epidemiology, Gestation \& Perinatal outcome $2^{\text {nd }}$ ed. (pp. 24651). Taylor \& Francis.

Cooke R.W.I.(2010) Does neonatal and infant neurodevelopmental morbidity of multiples and singletons differ? Seminars in fetal \& neonatal medicine, 15, 362-326.

Cunningham G.F., MacDonald P.C., Gant N.F., Leveno K.J., Gilstrap III L.C., Hankins G.D.V., Clark S.L.(1997) Williams Obstetrics $20^{\text {th }}$ Ed, p.873, Appleton \& Lange.

D’Amico M., Agozzino E., Biagino A., Simonetti A., Marinelli P. (1999). Ill-defined and multiple causes on death certificates - A study of misclassification in mortality statistics. European journal of epidemiology, 15, 141-148.

Ekholm Selling K., Carstensen J., Finnström O., Josefsson A., Sydsjö G. (2008).

Hospitalizations in adolescence and early adulthood among Swedish men and women born preterm or small for gestational age. Epidemiology, 19, 63-70

Fellman J., Erikson A.W. (2005).Variations in the maternal age effect on twinning rates: the Nordic experience. Twin research and human genetics, , 8, 515-523

Goldenberg R.L., Culhane J.F., Iams J.D., Romero R.(2008). Epidemiology and causes of preterm birth. The Lancet, 371, 75-84

Imaizumi Y. Trends of twinning rates in ten countries, 1972-1996.(1997). Acta geneticae medicae et gemellologiae, 46, 209-218

Johansson L.A., Westerling R. (2000) Comparing Swedish hospital discharge records with death certificates: implications for mortality statistics. International journal of 
epidemiology, 29, 495-502.

Kirkwood B.R., Sterne J.A.C. Medical Statistics. 2nd ed. Oxford: Blackwell Science; 2003.

Marsal K., Persson P.H., Larsen T., Lilja H., Selbing A., Sultan B. (1996) Intrauterine growth curves based on ultrasonically estimated foetal weights. Acta Paediatrica, 85, 843-848.

Moster D., Lie R.T., Markestad T. (2008) Long-term medical and social consequences of preterm birth. The New England journal of medicine, 359, 262-273

Montgomery K.S ., Cubera S., Belcher C., Patrick D., Funderburk H., Melton C., Fastenau M., (2005) Childbirth education for multiple pregnancy part1: prenatal considerations. The Journal of Perinatal Education, 14(2),26-35

Montgomery K.S ${ }^{\mathrm{b}}$, Cubera S., Belcher C., Patrick D., Funderburk H., Melton C., Fastenau M., (2005) Childbirth education for multiple pregnancy part1: intrapartum and postpartum considerations. The Journal of Perinatal Education, 14(3),33-38

National Board of Health and Welfare ${ }^{\text {a }}$, Centre for Epidemiology. Kodningskvalitet $i$ patientregistret, Slutenvård 2008. 2010. Retrieved 1 Mar, 2012, from http://www.socialstyrelsen.se/Lists/Artikelkatalog/Attachments/18082/2010-6-27.pdf

National Board of Health and Welfare ${ }^{\mathrm{b}}$, Centre for Epidemiology. Causes of death 2008. Stockholm, Sweden: National Board of Health and Welfare, 2008. 2010. Retrieved 1 Mar, 2012, from http://www.socialstyrelsen.se/Lists/Artikelkatalog/Attachments/18014/2010-4-31.pdf

National Board of Health and Welfare ${ }^{\mathrm{c}}$, Centre for Epidemiology. Dödsorsaksstatistik Historik, produktionsmetoder och tillförlitlighet, 2010. Retrieved 1 Mar, 2012, from http://www.socialstyrelsen.se/Lists/Artikelkatalog/Attachments/18019/2010-4-33.pdf

National Board of Health and Welfare, Centre for Epidemiology. Statistics - Health and 
medical care, pregnancies, deliveries and newborn infants, the Swedish Medical Birth Register 1973-2007, Assisted reproduction, treatment 1991-2006. 2009. Retrieved 1 Mar, 2012, from http://www.socialstyrelsen.se/Lists/Artikelkatalog/Attachments/17862/2009-12-11.pdf

National Board of Health and Welfare, Centre for Epidemiology. Kvalitet och innehåll $i$ patientregistret - Utskrivningar från slutenvård 1964-2006 och besök $i$ öppenvård (exklusive primärvårdsbesök) 1997-2006. 2008. Retrieved 1 Mar, 2012, from http://www.socialstyrelsen.se/Lists/Artikelkatalog/Attachments/8708/2008-1251_20081251_rev.pdf

National Board of Health and Welfare, Centre for Epidemiology. The Swedish Medical Birth Register; A summary of content and quality. 2003. Retrieved 1 Mar, 2012, from http://www.socialstyrelsen.se/Lists/Artikelkatalog/Attachments/10655/2003-112-

\section{3_20031123.pdf}

Quinn G.E., Gilbert C., Darlow B.A., Zin A.. (2010) Retinopathy of prematurity: an epidemic in the making. Chinese medical journal, 123, 2929-2937

Romero R., Mazor M., Munoz H., Gomez R., Galasso M., Sherer D.M. (2008) The preterm labor syndrome. Annals of the New York Academy of Sciences, 734, 414-429.

Scher A.I., Petterson B., Blair E., Ellenberg J.H., Grether J.K., Haan E., et al. (2002) The risk of mortality or cerebral palsy in twins: A collaborative population-based study. Pediatric research, 52, 671-681

Segal, N.L. (2011) Twins' injuries and environmental risks / twin research reports / human interest stories. Twin research and human genetics, 14, 213-216

Statistics Sweden. Multi-Generation Register 2009; a description of contents and quality. 2010. Retrieved 1 Mar, 2012, from 
http://www.scb.se/statistik/_publikationer/BE9999_2009A01_BR_BE96BR1003.pdf

Statistics Sweden $^{\mathrm{a}}$. Description of the population in Sweden 2008. 2009. Retrieved 1 Mar, 2012, from

http://www.scb.se/statistik/_publikationer/BE0101_2008A01_BR_BE0109TEXT.pdf

Statistics Sweden ${ }^{\mathrm{b}}$. Educational attainment of the population 2008. 2009. Retrieved 1 Mar, 2012, from

http://www.scb.se/Statistik/UF/UF0506/2008A01D/UF0506_2008A01D_SM_UF37SM 0901.pdf.

Statistics Sweden. Evalvering av utbildningsregistret. 2006. Retrieved 1 Mar, 2012, from http://www.scb.se/statistik/_publikationer/BE9999_2006A01_BR_BE96ST0604.pdf

Statistics Sweden. A new total population register system. More possibilities and better quality. (Serial no. 2002:2). 2002, Statistics Sweden: Örebro, Sweden.

Statistics Sweden. Population and Housing Census 1970 (SOS). Part 12. Report on the planning and processing of the Population and Housing Census 1970, (1974), National Central Bureau of Statistics: Stockholm, Sweden.

Tandberg A., BjØrge T., BØrdahl P.E., Skjaerven R. (2007)Increasing twinning rates in Norway, 1967-2004: the influence of maternal age and assisted reproductive technology (ART). Acta obstetricia et gynecologica Scandinavica, 86, 833-839 


\section{Legends}

Figure 1. Hospitalization odds ratios and corresponding 95\% confidence interval, for nonoptimal twins vs. optimal twins and non-optimal singletons vs. optimal singletons, respectively.

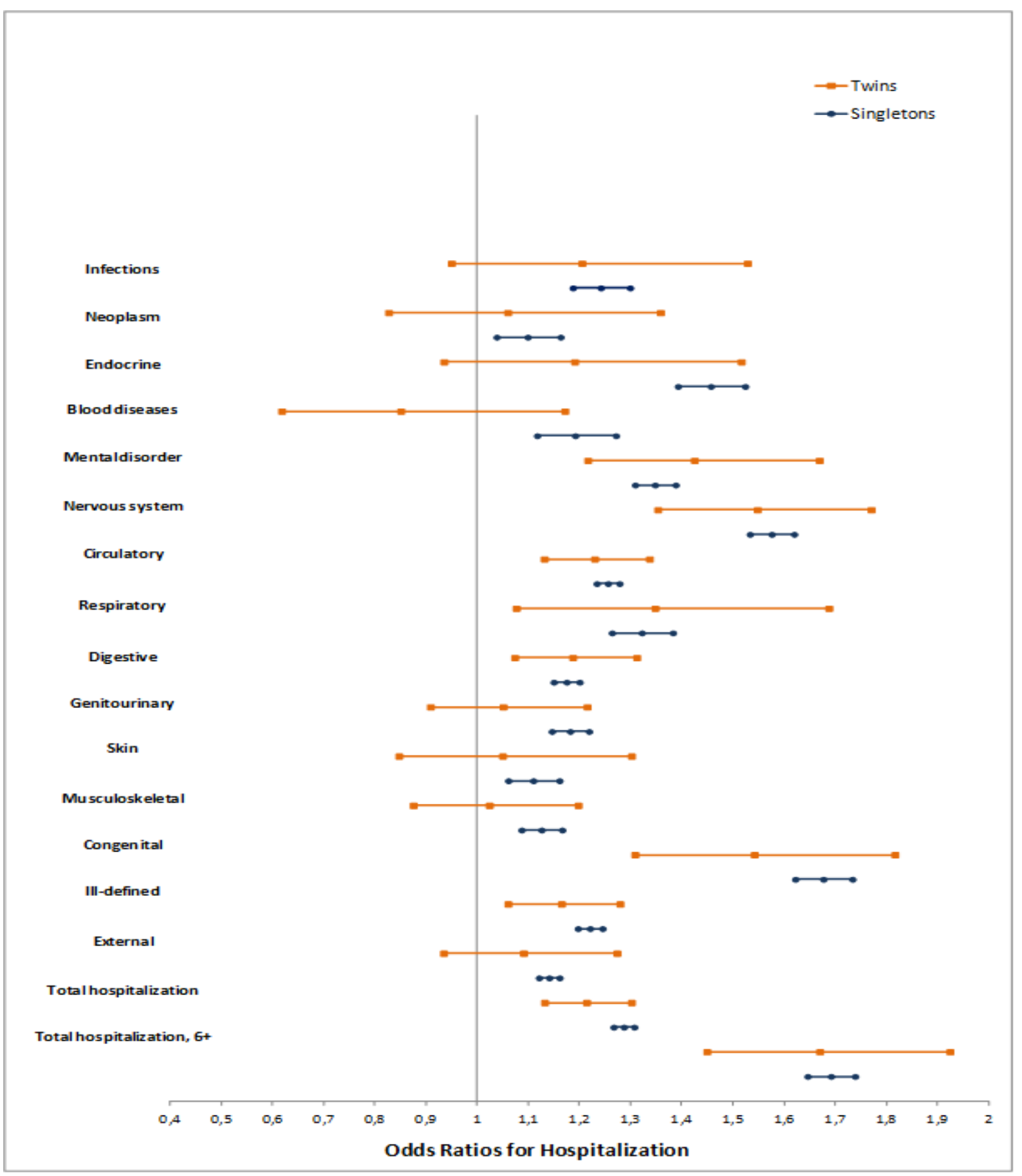


Table 1. Parental socio-demographic characteristics of singletons and twins born in Sweden 1973-1983 and living in Sweden at the age of $13^{\mathrm{a}}$ Sweden 1973-1983 and living in Sweden at the age of $13^{\mathrm{a}}$

\begin{tabular}{|c|c|c|c|c|}
\hline $\begin{array}{l}\text { Socio-demographic } \\
\text { characteristics }\end{array}$ & $\begin{array}{l}\text { Singletons } \\
(\mathrm{n}=1,000,127)\end{array}$ & $\begin{array}{l}\text { Twins } \\
(\mathrm{n}=16,561)\end{array}$ & $\begin{array}{l}\text { Twin versus } \\
\text { singleton } \\
\text { Univariate } \\
\text { OR }(95 \% \mathrm{CI})\end{array}$ & $\begin{array}{l}\text { Twin versus } \\
\text { singleton } \\
\mathrm{OR}^{\mathrm{b}}(95 \% \mathrm{CI})\end{array}$ \\
\hline \multicolumn{5}{|c|}{ Mother's educational level } \\
\hline 9-10 years & 285,791 & 4,702 & reference level & reference level \\
\hline $11-13$ years & 421,825 & 6,726 & $0.97(0.93-1.01)$ & $0.97(0.94-1.01)$ \\
\hline$\geq 14$ years & 226,392 & 1,100 & $1.08(1.04-1.13)$ & $1.01(0.97-1.06)$ \\
\hline Missing\$ & 66,119 & 1,100 & $1.01(0.95-1.08)$ & $1.09(1.01-1.17)$ \\
\hline \multicolumn{5}{|c|}{ Fathers educational level } \\
\hline 9-10 years & 315,135 & 5,192 & reference level & reference level \\
\hline $11-13$ years & 398,151 & 6,485 & $0.99(0.95-1.02)$ & $0.99(0.95-1.02)$ \\
\hline$\geq 14$ years & 211,639 & 3,745 & $1.07(1.03-1.12)$ & $1.06(0.96-1.05)$ \\
\hline Missing\$ & 74,838 & 1,139 & $0.92(0.87-0.98)$ & $0.94(0.88-1.01)$ \\
\hline \multicolumn{5}{|c|}{ Mother's marital status } \\
\hline Married & 693,565 & 11,921 & reference level & reference level \\
\hline Unmarried & 271,872 & 3,913 & $0.84(0.81-0.87)$ & $0.99(0.95-1.03)$ \\
\hline Divorced/widowed & 34,690 & 727 & $1.22(1.13-1.32)$ & $1.10(1.02-1.19)$ \\
\hline \multicolumn{5}{|c|}{ Parents' country of origin } \\
\hline Both Nordic & 923,274 & 15,287 & reference level & reference level \\
\hline $\begin{array}{l}\text { One or both non- } \\
\text { Nordic }\end{array}$ & 76,853 & 1,274 & $1.00(0.94-1.06)$ & $0.98(0.92-1.04)$ \\
\hline \multicolumn{5}{|l|}{ Mother's age } \\
\hline 13-19 years & 55,834 & 569 & reference level & reference level \\
\hline 20-26 years & 443,373 & 6,301 & $1.39(1.28-1.52)$ & $1.30(1.19-1.48)$ \\
\hline 27-33 years & 399,872 & 7,474 & $1.83(1.68-2.00)$ & $1.62(1.47-1.77)$ \\
\hline$\geq 34$ years & 101,048 & 2,217 & $2.15(1.96-2.36)$ & $1.83(1.66-2.03)$ \\
\hline \multicolumn{5}{|l|}{ Mother's parity } \\
\hline $\begin{array}{l}\text { No previous } \\
\text { children }\end{array}$ & 727,884 & 5,938 & reference level & reference level \\
\hline Previous children & 572,243 & 10,623 & $1.34(1.30-1.38)$ & $1.18(1.14-1.22)$ \\
\hline \multicolumn{5}{|l|}{ Gender } \\
\hline Male & 513,801 & 8,313 & reference level & reference level \\
\hline Female & 486,326 & 8,248 & $1.05(1.02-1.08)$ & $1.05(1.02-1.08)$ \\
\hline \multicolumn{5}{|l|}{ Year of birth } \\
\hline 1973 & 100,022 & 1,482 & reference level & reference level \\
\hline 1974 & 101,829 & 1,598 & $1.06(0.99-1.14)$ & $1.06(0.98-1.13)$ \\
\hline 1975 & 95,853 & 1,509 & $1.06(0.99-1.14)$ & $1.06(0.98-1.14)$ \\
\hline 1976 & 91,238 & 1,408 & $1.04(0.97-1.12)$ & $1.03(0.95-1.10)$ \\
\hline 1977 & 89,393 & 1,369 & $1.03(0.96-1.11)$ & $1.01(0.94-1.09)$ \\
\hline 1978 & 86,558 & 1,467 & $1.14(1.06-1.23)$ & $1.11(1.03-1.19)$ \\
\hline 1979 & 89,183 & 1,645 & $1.24(1.16-1.34)$ & $1.19(1.11-1.28)$ \\
\hline 1980 & 90,112 & 1,533 & $1.15(1.07-1.23)$ & $1.10(1.02-1.18)$ \\
\hline 1981 & 87,433 & 1,514 & $1.17(1.09-1.26)$ & $1.11(1.04-1.20)$ \\
\hline 1982 & 84,033 & 1,494 & $1.20(1.12-1.29)$ & $1.14(1.06-1.22)$ \\
\hline 1983 & 84,473 & 1,542 & $1.23(1.15-1.32)$ & $1.16(1.08-1.25)$ \\
\hline
\end{tabular}

${ }^{a}$ Higher order of multiple births excluded from the analysis ( 3 or more)

${ }^{\mathrm{b}}$ Odds ratio adjusted for all variables presented in the table 
Table 2. Birth characteristics of singletons and twins born in Sweden 1973-1983 and living at the age of $13^{\mathrm{a}}$

\begin{tabular}{|c|c|c|c|c|}
\hline Birth characteristic & Singletons & Twins & $\begin{array}{c}\text { Twin versus singleton } \\
\text { Univariate } \\
\text { OR }(95 \% \text { CI })\end{array}$ & $\begin{array}{c}\text { Twin versus singleton } \\
\operatorname{OR}^{\mathrm{b}}(95 \% \mathrm{CI})\end{array}$ \\
\hline \multicolumn{5}{|c|}{ Birthweight for gestational age } \\
\hline $\begin{array}{l}\text { Appropriate for } \\
\text { gestational age }\end{array}$ & 936,903 & 12,880 & reference level & reference level \\
\hline Small for gestational age & 36,786 & 3,599 & $7.12(6.85-7.40)$ & $2.28(2.59-2.88)$ \\
\hline Large for gestational age & 26,438 & 82 & $0.23(0.18-0.28)$ & $0.21(0.17-0.26)$ \\
\hline \multicolumn{5}{|l|}{ Birthweight } \\
\hline $\begin{array}{l}\text { Normal birthweight, } \\
\geq 2,500 \mathrm{~g}\end{array}$ & 970,578 & 10,271 & reference level & reference level \\
\hline $\begin{array}{l}\text { Low birthweight, } 1,500 \mathrm{~g} \\
-2,499 \mathrm{~g}\end{array}$ & 27,501 & 5,911 & $17.49(15.64-19.55)$ & $5.82(5.50-6.15)$ \\
\hline $\begin{array}{l}\text { Very low birthweight, } \\
\quad<1,500 \mathrm{~g}\end{array}$ & 2,048 & 379 & $20.31(19.63-21.02)$ & $3.21(2.74-3.77)$ \\
\hline \multicolumn{5}{|l|}{ Gestational age } \\
\hline At term, $37-42$ weeks & 934,021 & 10,806 & reference level & reference level \\
\hline Post term, $>42$ weeks & 26,480 & 84 & $0.31(0.25-0.38)$ & $0.33(0.26-0.40)$ \\
\hline Preterm, 32-36 weeks & 39,308 & 5,126 & $14.20(12.94-15.57)$ & $4.48(4.26-4.70)$ \\
\hline Very preterm, $<32$ weeks & 3,318 & 545 & $11.27(10.89-11.67)$ & $3.46(3.12-4.04)$ \\
\hline
\end{tabular}

${ }^{a}$ Higher order of multiple births excluded from the analysis ( 3 or more)

${ }^{\mathrm{b}}$ Odds ratio adjusted for all variables listed in Table 1 
Table 3. Hospitalization in adolescence and young adulthood among twins and singletons born in Sweden 1973-1983, by diagnosis

\begin{tabular}{|c|c|c|c|c|}
\hline $\begin{array}{l}\text { Hospitalization diagnosis (ICD9 } \\
\text { Chapter No.) }\end{array}$ & $\begin{array}{c}\text { Singletons } \\
(\mathrm{n}=1,000,127)\end{array}$ & $\begin{array}{c}\text { Twins } \\
(\mathrm{n}=16,561)\end{array}$ & $\begin{array}{r}\text { Twin v } \\
\text { hospita } \\
\mathrm{OR}^{\mathrm{a}}\end{array}$ & $\begin{array}{l}\text { singleton } \\
\text { zation } \\
95 \% \mathrm{CI})\end{array}$ \\
\hline $\begin{array}{l}\text { Infections and parasitic diseases } \\
\text { (1) }\end{array}$ & 105,167 & 1,944 & 1.14 & $(1.08-1.20)$ \\
\hline Neoplasm (2) & 16,463 & 277 & 1.03 & $(0.91-1.17)$ \\
\hline $\begin{array}{l}\text { Endocrine, nutritional and } \\
\text { metabolic diseases and immunity } \\
\text { disorders (3) }\end{array}$ & 20,688 & 370 & 1.08 & $(0.96-1.22)$ \\
\hline Blood diseases (4) & 11,400 & 169 & 0.91 & $(0.78-1.07)$ \\
\hline Mental disorders (5) & 50,815 & 819 & 0.98 & $(0.91-1.06)$ \\
\hline $\begin{array}{l}\text { Diseases of the nervous system } \\
\text { and sense organs (6) }\end{array}$ & 60,109 & 1,158 & 1.18 & $(1.10-1.26)$ \\
\hline $\begin{array}{l}\text { Diseases of the circulatory } \\
\text { system (7) }\end{array}$ & 13,495 & 222 & 1.01 & $(0.88-1.16)$ \\
\hline $\begin{array}{l}\text { Diseases of the respiratory } \\
\text { system (8) }\end{array}$ & 168,222 & 2,763 & 0.99 & $(0.95-1.04)$ \\
\hline $\begin{array}{l}\text { Diseases of the digestive system } \\
\text { (9) }\end{array}$ & 112,457 & 1,950 & 1.06 & $(1.01-1.12)$ \\
\hline $\begin{array}{l}\text { Diseases of the genitourinary } \\
\text { system (10) }\end{array}$ & 57,444 & 868 & 0.93 & $(0.86-1.00)$ \\
\hline $\begin{array}{l}\text { Diseases of the skin and } \\
\text { subcutaneous tissue (12) }\end{array}$ & 24,325 & 388 & 0.97 & $(0.87-1.08)$ \\
\hline $\begin{array}{l}\text { Diseases of the musculoskeletal } \\
\text { system and connective tissue } \\
\text { (13) }\end{array}$ & 43,588 & 696 & 0.98 & $(0.90-1.06)$ \\
\hline Congenital anomalies (14) & 36,671 & 711 & 1.18 & $(1.09-1.28)$ \\
\hline $\begin{array}{l}\text { Symptoms, signs and ill-defined } \\
\text { conditions (16) }\end{array}$ & 153,143 & 2,337 & 0.92 & $(0.88-0.97)$ \\
\hline $\begin{array}{l}\text { External causes of morbidity and } \\
\text { mortality }(17,18)\end{array}$ & 239,409 & 4,228 & 1.10 & $(1.06-1.15)$ \\
\hline Total (any hospitalization) & 379,786 & 6,204 & 1.04 & $(1.00-1.07)$ \\
\hline Hospitalized $\geq 6$ times & 55,544 & 1,047 & 1.17 & $(1.09-1.25)$ \\
\hline
\end{tabular}

${ }^{a}$ Odds ratio adjusted for all variables listed in Table 1. 
Table 4. Hospitalization odds ratios during adolescence and young adulthood in twins vs. singletons born

in Sweden 1973-1983, by diagnosis and birth characteristics (optimal*/non-optimal**)

\begin{tabular}{|c|c|c|c|}
\hline Hospitalization diagnosis (ICD9 Chapter No.) & $\begin{array}{l}\text { Optimal twin } \\
\text { vs. optimal singleton } \\
\mathrm{OR}^{\mathrm{a}}(95 \% \mathrm{CI})\end{array}$ & $\begin{array}{l}\text { Non-optimal twin } \\
\text { vs. non-optimal } \\
\text { singleton } \\
\text { OR }^{\text {a }}(95 \% \mathrm{CI})\end{array}$ & Non-optimal twin vs. non-optimal singleton \\
\hline Infections and parasitic diseases (1) & $1.06(0.89-1.26)$ & $1.01(0.86-1.20)$ & $0.99(0.69-0.96)$ \\
\hline Neoplasm (2) & $0.99(0.84-1.20)$ & $0.99(0.83-1.18)$ & $0.99(0.82-1.18)$ \\
\hline $\begin{array}{l}\text { Endocrine, nutritional and metabolic diseases and } \\
\text { immune disorders ( } 3 \text { ) }\end{array}$ & $1.03(0.86-1.23)$ & $0.82(0.69-0.97)$ & $0.81(0.69-0.96)$ \\
\hline Blood diseases (4) & $0.99(0.80-1.23)$ & $0.70(0.55-0.89)$ & $0.69(0.54-0.88)$ \\
\hline Mental disorders (5) & $0.83(0.74-0.94)$ & $0.88(0.79-0.98)$ & $0.87(0.78-0.97)$ \\
\hline Diseases of the nervous system and sense organs (6) & $0.97(0.87-1.08)$ & $0.94(0.86-1.03)$ & $0.88(0.81-0.97)$ \\
\hline Diseases of the circulatory system (7) & $0.94(0.77-1.15)$ & $0.89(0.74-1.08)$ & $0.86(0.71-1.05)$ \\
\hline Diseases of the respiratory system (8) & $0.87(0.82-0.93)$ & $0.87(0.82-0.93)$ & $0.83(0.78-0.89)$ \\
\hline Diseases of the digestive system (9) & $0.99(0.92-1.07)$ & $0.99(0.92-1.06)$ & $0.96(0.89-1.03)$ \\
\hline Diseases of the genitourinary system (10) & $0.92(0.83-1.02)$ & $0.82(0.74-0.91)$ & $0.81(0.73-0.90)$ \\
\hline Diseases of the skin subcutaneous tissue (12) & $0.96(0.83-1.12)$ & $0.90(0.77-1.05)$ & $0.88(0.75-1.03)$ \\
\hline $\begin{array}{l}\text { Diseases of the musculoskeletal system and connective } \\
\text { tissue (13) }\end{array}$ & $0.97(0.87-1.09)$ & $0.88(0.79-0.99)$ & $0.87(0.78-0.98)$ \\
\hline Congenital anomalies (14) & $0.98(0.86-1.11)$ & $0.90(0.81-1.03)$ & $0.86(0.77-0.96)$ \\
\hline Symptoms, signs and ill-defined conditions (16) & $0.87(0.81-0.93)$ & $0.81(0.76-0.87)$ & $0.80(0.75-0.85)$ \\
\hline External causes of morbidity and mortality $(17,18)$ & $1.07(1.02-1.13)$ & $1.02(0.97-1.07)$ & $1.01(0.96-1.06)$ \\
\hline Total (any hospitalization) & $0.96(0.92-1.01)$ & $0.90(0.86-0.95)$ & $0.87(0.83-0.92)$ \\
\hline Hospitalized $\geq 6$ times & $0.92(0.83-1.03)$ & $0.90(0.83-1.03)$ & $0.86(0.78-0.94)$ \\
\hline
\end{tabular}

*Born at term and appropriate for gestational age **Born preterm and/or small for gestational age

${ }^{a}$ Odds ratio adjusted for socio-demographic variables presented in Table 1.

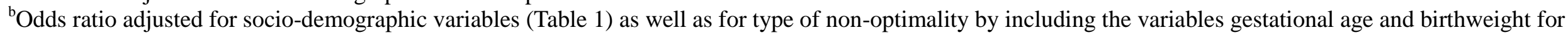
gestational age (Table 2). 